\title{
Metamodern Gaming: Literary Analysis of The Last of Us
}

\author{
SIMON RADCHENKO
}

\begin{abstract}
Among numerous ways to describe the culture and literature after postmodernism metamodern is becoming more and more popular. Its main features - oscillation, affect, desire for structure and (re)construction etc. appear in many products of contemporary culture. This article reflects the endeavour to apply metamodernism and its trends to the literary analysis of cybertext. Crucial trends of metamodernism are briefly described and implemented in the analysis of a video game. The features of cybertext that influence the analysis are considered. All these instruments were used to show the metamodern nature of the game by Naughty Dog, The Last of Us (2013). The article attempts to analyze a cybertext through the methods of literary analysis and reveal metamodern ideas in The Last of Us using main metamodern categories as a tool for text study.
\end{abstract}

Keywords: metamodernism; postmodernism; cybertext; oscillation; affect; The Last of Us

\section{Introduction}

The infinite spirit of postmodernism that conquered European culture and literature since the middle of the last century has already heard dozens of proclamations about its death. Yet, the most massive and noticeable belongs to David Foster Wallace and his Infinite Jest (1996). Since his novel and a number of essays ${ }^{1}$ were published, post-postmodernism, as a method of considering literature, has reached a vast audience of writers and literary critics. Infinite Jest has already been discussed many times from the perspective of postmodernism and contemporary art. Indeed, the grotesquely postmodern style is combined here with the ideas and stories that are far from being postmodern.

Following Wallace's concept or proceeding from it, researchers in literature and culture began criticizing postmodernism and started to look for a new approach that was hastily called post-postmodernism. Some notes on

1 See, for example, Certainly the End of Something or Other, One Would Sort of Have to Think (Wallace 2007) or E Unibus Pluram: Television and U.S. Fiction (Wallace 1993). 
postmodernism's weaknesses refer to its actuality and capacity to describe contemporary literature - the contemporary writing can barely be interpreted through postmodern lenses. It also means that postmodern concepts can no longer be of any use when studying and describing contemporary culture (Vermeulen and van den Akker 2010; Hatcheon 2002: 165 - 166). The other problem is that the deconstructive and skeptic nature of postmodernism narrows the possibility of considering the future, and thus, following Frederic Jameson, leaves the world two-dimensional and replaces the depth (of the future) by a surface (of contemporaneity) (Jameson 1991: 12).

Catching and understanding the new trend, many have tried to describe and name it during the process of its birth. Among all of these concepts ${ }^{2}$, altermodernism, performatism, digimodernism and automodernity became the most widely discussed and popular (Morgado 2014: 315; Kirby 2010). While being able to describe some aspects of contemporary culture, they have provoked justified criticism at different points - dependency on postmodernism, lack of brand-new concepts, lack of argumentation (altermodernism) etc. Others avoid or fail to reflect the state of art or are based only on technical changes (performatism, digimodernism, automodernity), and thus cannot be used to understand current cultural trends and movements. As Alan Kirby notices concerning his own idea, the world of digimodernism is a cultural desert, as it is empty without interacting characters (Kirby 2006).

As well as specific concepts, post-postmodernism in general has also been critically reviewed. The discussion about "is it something new or just a part of postmodernism" still continues (Tabbi 2017). Post-postmodernism's lack of independence was noticed by Stephen J. Burn (2008), who mentions that "it is hard to feel good about the explanatory value of a term whose usage collapses the differences between such different writers and contexts" and "a more serious dimension of a post-postmodernism's filial relationship to postmodernism is the continuity of the kind of ambition to produce the encyclopedic master-work that I identified ... as a characteristic impulse within postmodernism" (Burn 2008: 19-20).

2 For a short summary see, for example, Morgado 2014 or Vermeulen and van den Akker 2010 or works such as Alan Kirby, The Death of Postmodernism And Beyond (2006); Raoul Eshelman, Performatism or the End of Postmodernism (2008); Nicolas Bourriaud, The Radicant (2009). 


\section{Metamodernism as an Analytical Method}

Since postmodernism is no longer useful when interpreting contemporary literature, we urgently need to find a new 'understanding toolkit' based on post-postmodern approaches. Without an instrument to reveal and chase the core ideas of art instances, we are at a continuous risk of misunderstanding the development of cultural processes. From this standpoint the most promising post-postmodern concept is metamodernism as it tries to encompass the current state of art and culture, the components and trends beyond that state, or (following the authors of it), the structure of a new feeling.

Although Timotheus Vermeulen and Robin van den Akker claimed that they had just attempted to describe the feeling of the new century and did not intend to create any strategy, theory or philosophy (Vermeulen and van den Akker 2015), metamodernism as a package of features characterizes the current world and the art around us very well. Furthermore, as metamodernism became more popular, they tried to implement some aspects of it to describe some cultural trends (see van den Akker, Gibbons, Vermeulen 2017). Van den Akker even made a list of the most important and bright metamodern features: "postirony, constructive participation endeavours, communicative form of an affect, craft development and storytelling" in his interview to Syundukov and Svishchenko (2016). This list is not unique, as many more "post-postmodern" (see, for instance, Timmer 2010) or "metamodern" (Freinacht 2015) lists have been published in the last decade.

Having summed up the current state of the ecosystem and the geopolitical financial structure in their essay Notes on Metamodernism (Vermeulen and van den Akker 2010), the authors proclaimed the long holiday of postmodern mockery to have come to an end. Since their approach combines the philosophic background, the depiction of current processes and the more-or-less-satisfactory definition of new trends, the term 'metamodern' appears to be the most effective among other concepts of post-postmodernism. Besides, researchers claim that metamodernism is not entirely separated from postmodernism but is rather between modernism and postmodernism; it is both and none of them at the same time, simultaneously above and inside this superposition. The unstoppable oscillation between the modern and postmodern concepts is the general mark of metamodernism that produces its other features.

Despite some critical reviews of Notes on Metamodernism (Eve 2012; Kardash 2019) regarding its bold proclamations and discussable use of the Kantian 'as if', the essay still appears to be very accurate and complex in defining the aspects that have flooded contemporary art. 
Trying to adopt all of them for the purposes of literary analysis, I defined and tested a number of features that identify a text as metamodern. Some of them were combined or enriched, some were partially reconsidered and some I was forced to avoid for the sake of usability, but the result fits more or less into the ideas of researchers mentioned above. This instrument was already described and applied to search for metamodern trends in Thomas Pynchon's Bleeding Edge, so below a brief summary is provided (Radchenko 2019). The chosen points of metamodern agenda are:

1. Oscillation between modern and postmodern, old and new, skepticism and faith and other different poles. The reason for doubts and oscillation lies in a desire to search for the truth, for the depth of the 'third-dimension' (Dempsey 2015), while the postmodern experience teaches us that such a search is fruitless. The consequence of it is the nostalgia for the good old days of postmodern skepticism when avoiding adopting a position and staying neutral were efficient.

2. The desire to feel and to be emotional instead of being ironic is the approach that Wallace called "a new sincerity". It was combined with other concepts into the term the metamodern affect (Gibbons 2017). The crucial idea lies in understanding that "irony, poker-faced silence, and fear of ridicule are distinctive of ... features of contemporary U.S. culture" (Wallace 1993: 171), so feeling and sharing become very important again. Thus, a metamodern text is intended to be emotional and provoke emotions at the same time. "The post-postmodern novel is not 'beyond irony', or itself completely 'irony free', but it no longer uses irony as the default 'language', irony is no longer the cultural convention or cultural norm in the novel itself" (Timmer 2010: 360). The same applies to mockery. Metamodern characters' acts proceed from the standpoint of emotions, unlike the skeptical postmodern protagonists who sometimes behave as some kind of superheroes. As they cannot be ironic and skeptical any more, they need to have faith in something, for instance, in the endless search for the truth.

3. Metamodern language utility replaces endless postmodern lists, references and quotations. While it is typical of postmodern feelings to hide behind the wall of text and symbols (something that Mickael Bakhtin calls carnival language (see Bakhtin 1990: 15-17, Radchenko 2017)) and pretend to be smart and intelligent, metamodern ones avoid that. For the purpose of sharing emotions and metamodern affect, contemporary texts try to convey and satisfy the emotions instead of the mind. Besides, as postmodern mockery fades away, the practical purpose of communication arises. Unlike the postmodern characters, the current ones believe that they have a goal (a result of their search) they try to reach by communicating.

4. As the affect and desire to search arise, new heroes do not want to be sarcastic postmodern loners any more. Instead, they struggle to belong to some 
structure or system, to be together. The will to belong to some social formation is connected to the need for sharing emotions and choosing a side because belief is always about choosing sides. Metamodernism reinvents social rules and hierarchies that were considered bad and silly during the postmodern era.

5. The last and the most important is the constructive nature of metamodern. This is the reason for and the consequence of all other aspects. As the destructive postmodernism left the social and cultural horizons empty, there is a need to (re)construct (Huber 2014: 7), (re)invent a new truth, new sincerity, new sociality and new systems. It is important to share and belong to something and yet, without emotional sharing, sociality and efficient communication, the construction of a new world is impossible. Consequently, the constructive participation and constructive search are the main aspects of the metamodern worldview.

Further analysis is based on the search and interpretation of these features in specific texts. Several researchers use slightly different approaches to confirm that they belong to the metamodern paradigm. Metamodern views can be found in contemporary literature as well as in other cultural spheres. What if we were to try to analyze something simultaneously similar and different, using this method of literary analysis? What about videogames?

\section{A Few Words on Cybertext}

To do that we must consider some important details of videogames and how they interact with the reader (i.e. the player). The category of texts that games belong to is called cybertext. Cybertext "centers attention on the consumer, or user, of the text, as a more integrated figure than even reader-response theorists would claim" and proposes "... physical construction that the various concepts of "reading" do not account for" (Aarseth 1997: 1). Aarseth notices that cybertext is not limited to the modern technologies but was available centuries before, for instance, in Egyptian temples or the book of I Ching. As cybertext constantly requires a reader to develop the story, it opens new horizons for interaction with the described world, heroes and plot. Unlike literature or cinema, the characters are never alone as the player usually knows he can change something according to his own ideas. The third person, e.g. the player, who doubts, feels and travels together with game characters should be constantly considered.

Since this kind of text proposes much more involvement and presence, or, in a more complex term, incorporation (for a detailed analysis see Calleja 2011), obviously the player's involvement is much more intense. “The player's active 
input creates the potential for a more intense emotional experience, whether satisfying or frustrating, than non-ergodic media provide" (Calleja 2011: 135). This concept is extremely important as it influences the metamodern affect that forces the player to be a part of an emotional story. Whenever the game character is scared, angry, happy or sad, he is intended to transfer these emotions to a real person. Even without emotions on the screen, the player is still capable of reacting emotionally to the action. The affective involvement must be also taken into account when talking about the metamodern affect.

Despite everything mentioned above, cybertext is still a text that "produces verbal structures for aesthetic effect" (Aarseth 1997: 3). Since videogames mostly transmit information using visual instruments, what is left for literary analysis are plot and dialogues. Such a situation relates the videogame to the interactive drama. It can make the analysis more complicated, but since we are interested in content and transcendent senses rather than in forms and specific symbols, our method and chosen criteria are still useful.

Since we search for cultural trends and apply literary analysis, it is important to choose a videogame that contains some cultural ideas and is more or less satisfactory as a text. Both Tetris and World of Warcraft, the classics and most popular examples of videogames, barely fit the description, as they do not tell a story or reveal any clear and contemporary cultural idea. The Last of Us (Naughty Dog 2014), is popular because of a well-written plot, charming characters and atmospheric environment. The game was released in 2013 and remastered in 2014, receiving a lot of positive reviews and reaching a large audience of fans. It was called "visually arresting, mechanically solid, maturely written" (Sartori 2013) and a "unique and satisfying competitive experience" (Mc Shea 2014). It has already become a subject in researches on different issues but was never investigated from a literary standpoint (Farca and Ladeveze 2016; Green 2015).

\section{Metamodernism and The Last of $U$ s}

The story takes place in the nearest future, in the post-apocalyptic United States. Twenty years previously, a brain infection affected humanity, turning them into infectious zombies. The old world collapsed and people were forced to radically change their lifestyle, living in terror and uncertainty ${ }^{3}$. People live in reservations under military control or fight for survival in the wild. Most of the land surface is

A catastrophe that finalizes the calm and peaceful period is already familiar to metamodern style - the same feeling is conveyed by the first lines of Notes on Metamodernism, some ideas of Alan Kirby (2006) or Thomas Pynchon's Bleeding Edge. 
crowded by the infected. Only one organization - Fireflies - fights for the future of humanity by searching for the vaccine. The player travels together with two main characters - Joel and Ellie. Joel is an almost 50-year-old soldier of fortune who lost his daughter on the day apocalypse started. Ellie is a fourteen-year-old girl who was born in the new world and never saw peaceful and safe life. Being immune to the disease, she travels with Joel to the hospital to create the vaccine and save humanity. As they travel, their goal moves further away, prolonging their search. During the journey characters share emotions with each other and the player; discuss their worldview and intentions; face danger and try to avoid it the story in general is written (created) in coherence with metamodern features and trends and further below I will try to describe and show that.

The general concept and the main quest of the whole game is the search for the Fireflies lab. The farther the characters move, the farther away is their goal. Beginning with a small quest inside a city, it ends on the other side of the continent. And while the story moves forward, characters keep questioning the necessity of the quest. Even at the very end Joel points out that they "don't have to do this" (Naughty Dog 2014, Joel). Trying to get rid of Ellie from time to time, he decides not to leave her when this opportunity arises. "And we are going our separate ways," (Naughty Dog 2014, Joel) he says, and right in the next scene changes his mind again.

Joel is the most oscillating character in the game. Since he lost his daughter, he avoids sharing emotions with other people. He forbids Ellie to talk about Tess and her death, but in the same situation later decides to share his emotions on the subject: "Look, Bill, um, about your buddy back there. Uh... That's a tough deal. And I'm ah..." (Naughty Dog 2014, Joel). Later he refuses to look into his past again, avoiding photos and conversations on that topic.

Some characters even doubt the nature of infected humans: "Those things out there. What if the people are still inside? What if they are trapped in there without any control of their body," (Naughty Dog 2014, Sam) asks Sam a few hours before he turns out to be infected.

The most disturbing question for all the game characters, however, is if it is reasonable to believe in people and in the possibility of a bright future. One of the dead citizens who wrote a few notes on his last days says: "Yesterday I met some people $[\ldots]$ They had kids with them and they seemed pretty scared. I almost told them about that place. What if they're like the others? What if..." (Naughty Dog 2014, trading note). From another note we learn that he chooses to trust other people: "Every part of my being just wants to give up. It'd be so easy to surrender to this world. I can't do that, though. I have too much faith in humanity. I've seen that we are still capable of good" (Naughty Dog 2014, survival note). 
Metamodern Gaming: Literary Analysis of The Last of Us

As a metamodern person he had reasonable doubts but decided to trust people for a sentimental reason. The same can be said for Tess (Joel's companion as the game starts). While Joel denies Ellie's immunity to the infection, Tess believes in the girl without a reason:

JOEL: Tess, what the hell are we doing here?

TESS: What if it's true?

JOEL: I can't believe...

TESS: What if, Joel? I mean we've come this far, let's just finish it. (Naughty Dog 2014)

Despite all disappointments, almost every person in the videogame believes that a reason to survive and fight exists, even if there is none at the moment. "No matter what, you keep finding something to fight for," (Naughty Dog 2014, Joel) says Joel in the last scene of the story.

While all characters have their own doubts and considerations, they rarely share them with each other. In the same way they try to avoid philosophical debates or any extra debates at all. Their speech is usually short and clear, concentrated on specific purposes of a moment. Even the game itself helps the characters and tries to be as laconic as possible - all the introductory information comes as short sentences from a news report: "The number of confirmed has just passed two hundred. The Governor has called a state of emergency... Panic spread worldwide after a leaked report from the World Health Organization showed that the latest vaccination tests have failed" (Naughty Dog 2014, news report). Every written material avoids lists, references and specifications when possible.

To shorten location descriptions, characters use stereotypic, recognizable markers - Boston Capitol, University of Eastern Colorado, Saint Mary's Hospital in Salt Lake City etc.

Besides, when somebody desires to say more than required, other characters usually interrupt him to shorten the speech. The only audio record that can give us a complex impression of what happened was skipped by Joel to hear just the key information: "Got me some time to reflect... [Scrolling] ... been years that felt like we were... [Scrolling] ... fucking thing was a giant waste of time... [Scrolling] ... not gonna do this anymore... [Scrolling] ... looking for the others, they've all returned to the Saint Mary's Hospital in Salt Lake City" (Naughty Dog 2014, Firefly).

Despite the general language utility, characters try to show and share their emotions as much as possible. They are not sarcastic heroes and it is usual for them to be emotional and affected. This is even more important since the player is also affected by and involved with their feelings even though he / she might not 
like some characters' decisions. Since a videogame is intended to immerse users, scenes and dialogues are constructed so as to force them to be emotional. For instance, when Joel decides to leave Ellie with Tom instead of accompanying her to the Fireflies' lab. She is angry and sad and shares this with Joel: "Well, I guess we are both disappointed with each other than ... admit that you wanted to get rid of me the whole time ... Ah, fuck that" (Naughty Dog 2014, Ellie). Since the player does not want the characters to separate, he is frustrated together with Ellie and, in consequence, involved affectively. Similarly, at the end of the story the player decides if Joel has made the right decision (but only in his mind, without a chance to choose interactively). The users worry about Ellie's fate regardless of their attitude.

Most characters indicate when they are scared or sad. They attempt to be sincere and reflective about their feelings. And like typical metamodern characters, they share some naïve and irrational wishes:

SAM: How is that you are never scared?

ELLIE: Who says that I'm not?

SAM: What are you scared of?

ELLIE: Let's see... Scorpions are pretty creepy. Um... Being by myself. I'm scaring of ending up alone. What about you? $[\ldots]$

SAM: Henry says that they've moved on. That they're with their families. Like in heaven. Do you think that's true?

ELLIE: I go back and forth. I mean, I'd like to believe it. (Naughty Dog 2014)

Admiring the power of emotions, Tess uses them to convince Joel to leave her and get Ellie to the hospital: "I will not turn into one of those things. Come on. Make this easy for me [... ] Just fucking go" (Naughty Dog 2014, Tess).

Moreover, some characters force others to share and discuss emotions or wait for them to be sincere and open-hearted. While Joel tries to hide all his feelings, Ellie urges him to have some gratitude or just conversation:

JOEL: I'm glad I didn't get my head blown off by a goddamn kid.

ELLIE: You know what? No. How about, hey, Ellie, I know it wasn't easy, but it was either him or me, thanks for saving my ass. You got anything like that for me, Joel? (Naughty Dog 2014)

Joel refuses to talk about the dead, but the girl needs to ask him and she does:

ELLIE: I forgot to leave that stupid robot on his grave. What should I do with it? 
Metamodern Gaming: Literary Analysis of The Last of Us

JOEL: Ellie...

ELLIE: What? I want to talk about it.

JOEL: No [...] Things happen and we move on. (Naughty Dog 2014)

Characters are also quite emotional when it comes to the recollections of the old world, their nostalgia for life before infection. They share their memories intensely, dreaming of the time when everything was easy and everybody was safe. These memories generally have some symbolic meaning - they are about something small and commonplace, but impossible in this new post-apocalyptic life. Ellie cannot be nostalgic as she has not seen the old world. Her thoughts about the past are driven by curiosity: "Is this really all they had to worry about? Boys. Movies. Deciding which shirt goes with which skirt? It's bizarre" (Naughty Dog 2014, Ellie). On the contrary, Joel usually recalls some details or particular experiences: "You feel that breeze, huh? I tell you, on a day like this, I'd just sit on my porch, pick away at my six-string" (Naughty Dog 2014, Joel). Plagued by nostalgia, he even tries to explain to Ellie how to play baseball, though this knowledge is obviously useless now:

ELLIE: ...if you mess up your fourth down, then you give the ball to the other team?

JOEL: Right, it's called turnover

ELLIE: And if you clear the ten yards then you're back at... first down?

JOEL: First down, that's right

ELLIE: Man, it's confusing. (Naughty Dog 2014)

Other characters, like Henry, the survivor they've met at the end of the summer episode, also feels nostalgic. And sometimes it is fake nostalgia - they dream of something that they have never done in the past (fake memories and autofiction in general can also be considered as features of post-postmodernism):

JOEL: It was Tommy's birthday. That's all he wanted to do is just - rent two Harley's and drive cross country.

HENRY: Ah, man, I could die happy if I could just ride one around the block. $[\ldots]$ Ellie, Ellie, this isn't just any regular motorcycle. Okay? You get on that bad boy, you feel that engine. Nothing like it.

ELLIE: Oh yeah? How would you know?

HENRY: I've seen it in my dreams. ... Vroom, vroom, vroom... (Naughty Dog 2014)

Even the game itself endeavours to awaken the player's nostalgia by old blues in the car, comics magazines etc. But the characters do not think only about their 
past. This nostalgia also reveals their ephemeral plans for the future when the world is safe again. In the moments of nostalgia, not only are they immersed in the past, but they also try to look into the future to see something good and optimistic. These dreams are crucial to enforce their blind and irrational faith in the possibility of reconstructing the old world. And this is what all of them want.

The intention to construct is in the entire quest because the vaccine creation and the infection treatment are meant to restore the world to what it was before. For most game characters it is the most important objective: "Once they remove it [virus], they'll be able to reverse engineer a vaccine. A vaccine. ... This isn't about me. Or even her. There is no other choice here," (Naughty Dog 2014, Marlene) says Marlene, leader of the Fireflies. The cost of this reconstruction does not matter to her. Fireflies follow this idea: "This is our future. Think of all lives we'll save” (Naughty Dog 2014, doctor). Since Ellie is an opportunity for a new beginning, Joel, Tess and Tommy decide to help her in spite of their doubts, fears or the fact they have families. For them it is a "chance to save us... all of us. This is what we were after..." (Naughty Dog 2014, Marlene recorder 2 ). On the contrary, authorities in quarantine zones try to make it look like they are already in the old world - they have created schools, police stations, partially rebuilt cities etc. As a result, quarantine zones become cruel places, similar to an enemy-occupied country. Fireflies try to find followers by using emotions instead. "Remember when you're lost in the darkness look for the light. Believe in the Fireflies" (Naughty Dog 2014, news report). And it works - since they propose some protection, many people bet on them. However, Fireflies demand a "return of all branches of government" (Naughty Dog 2014, news report), i.e. reconstruction or recreation. The methods and approaches of all groups presented in the game are different, but their goal is the same - to create a nice and safe world and order, like those in the world before the epidemic. It works even for those who avoid either the Fireflies or the quarantine zones: "Remember how we thought no one could live like this anymore? Well, we're doing it" (Naughty Dog 2014, Tommy).

But a loner cannot construct any reliable model of the world. That is why people desire to be together - not to be alone any longer. Characters desire to gather into groups or bands and solve their survival issues together. It works for Fireflies, David's group, Tommy, Maria's commune and even the bandit formations. Usually these groups have a specific leader, and consequently a kind of hierarchy, as it should be in post-postmodern society. The main challenge for a member of such a group is to care about others: "First of all, we are a team now. We're gonna help each other out” (Naughty Dog 2014, Ellie). This also requires communication with other groups bearing in mind one's own interests: 
DAVID: We're from a larger group - women, children - we're all very, very hungry.

ELLIE: So am I - women and children - all very hungry too.

DAVID: Well, maybe we could ah, trade for you some of that meat here. What do you need? Weapons, ammo, clothes... (Naughty Dog 2014)

People are just trying to "take care of our own. By any means necessary" (Naughty Dog 2014, David). The existence of the group stops Tommy from helping Ellie in her quest. He desperately wants to stay, not wanting to leave his people and wife: "My cause is my family now. You ain't talk about some walk in the park here" (Naughty Dog 2014, Tommy).

What is even more intense than the "structure desire for 'we"" (Timmer 2010: 359 ) is the fear of being alone, abandoned by other human beings: "Everyone I have cared for has either died or left me. Everyone - fucking except for you. So don't tell me that I would be safer with someone else, because the truth is I would just be more scared" (Naughty Dog 2014, Ellie). Despite Joel's unkindness to the girl, she needs him (someone to believe in and someone to trust) to be near. Similarly, at the end of the novel Joel decides to save Ellie. He has two options: let the Fireflies kill the girl to create the vaccine and save the world or save Ellie's life instead. This is a very emotional and dramatic moment and the affective involvement of the player grows here since they (unlike contemporary trends) do not have a chance to choose a side - they follow Joel's wish even if it feels wrong (on the problem of choice and videogames see Gotterbarn 2010, 7-8). As Joel is afraid to lose the only person he is affected by, he stops the endeavour to create a vaccine just to avoid loneliness. While this decision is questionable, probably the real reconstruction is possible by saving not all the people but only those who stayed human in the new world of terror and ignorance.

All the afore-mentioned reveals the game characters to be metamodern. They oscillate, struggle and get affected as metamodern persons should. Even the entire world of the game seems to follow metamodern rules by admiring hierarchy, the social and structural needs of the population. Despite the fact we analyzed not a regular but a cybertext, the literary approach appeared to be fruitful and proved this game to belong to metamodern literature. It also means that the methods and tools of literary analysis can be used effectively to analyze video games or any other types of cybertext. The Last of Us seems to be a masterfully written story about people, their choices and emotions. It perfectly fits the structure of a new feeling, described as metamodern. Moreover, it teaches us about who we are and how to stay human even when facing the agony of humanity. 
RADCHENKO

\author{
Simon Radchenko \\ Simon.radchenko@gmail.com \\ Str. Ernsta, 2, apt. 201 \\ 03048 Kyiv \\ UKRAINE
}

\title{
Bibliography
}

Aarseth, E. J. 1997. Cybertext: Perspectives on Ergodic literature. Baltimore: The Johns Hopkins University Press.

Bakhtin, М. 1990. Творчество Франсуа Рабле и народнал культура Средневековья u Peнесcанса. / Tvorchestvo Fransua Rable i narodnaya kultura Srednevekovya i Renessansa. Moskow: Khudozhestvennaya literatura.

Burn, S. J. 2008. Jonathan Franzen at the End of Postmodernism. London: Continuum.

Calleja, G. 2011. In-game: from Immersion to Incorporation. Massachusetts: The MIT Press.

Dempsey, B. 2015. “[Re]construction: Metamodern 'Transcendence' and the Return of Myth," Notes On Metamodernism, https://www.metamodernism. com/2014/10/21/reconstruction-metamodern-transcendence-and-the-return-ofmyth/ (15.11.2019).

Eve, M. P. 2012. Thomas Pynchon, David Foster Wallace and the Problems of "Metamodernism": Post-Millennial Post-Postmodernism? - C21 Literature: Journal of 21st-Century Writings, 1, 7-25.

Farca, G., Ladeveze, C. 2016. The Journey to Nature: The Last of Us as Critical Dystopia. - Proceedings on the first International joint Conference of DiGRA and FDG, 1 (13), 1-16.

Freinacht, H. 2015. 5 Things That Make You Metamodern. - Metamoderna, http:// metamoderna.org/5-things-that-make-you-metamodern?lang=en (15.11.2019).

Gibbons, A. 2017. Contemporary Autofiction and Metamodern Affect. - R. van den Akker, A. Gibbons, T. Vermeulen, eds., Metamodernism: Historicity, Affect, and Depth after Postmodernism. Maryland: Rowman \& Littlefield International, 117-130.

Gotterbarn, D. 2010. The Ethic of Video Games: Mayhem, Death, and the Training of the Next Generation. - Information System Frontiers, 4, 369-377. https://doi. org/10.1007/s10796-009-9204-x

Green, A. M. 2015. The Reconstruction of Morality and the Evolution of Naturalism in The Last of Us. - Game and Culture, 11 (7-8), 745-763. https://doi. org/10.1177/1555412015579489

Hutcheon, L. 2002. The Politics of Postmodernism. New York; London: Routledge.

Jameson, F. 1991. Postmodernism, or the Cultural Logic of Late Capitalism. Durham: Duke University Press.

Joseph T. 2017. Pynchon: on the Reading Scene, behind the Scenes of the Letter. Paper presented at the public lecture, Kiev, December. 
Metamodern Gaming: Literary Analysis of The Last of Us

Kardash, A. 2019. A Critique of Metamodern Philosophic Basement. - Syg.ma, https:// syg.ma/@insolarance-cult/kritika-filosofskikh-osnovanii-mietamodierna (15.11. 2019).

Kirby, A. 2009. Digimodernism: How New Technologies Dismantle the Postmodern and Reconfigure Our Culture. New York; London: Continuum.

Kirby, A. 2010. Successor States to an Empire in Free Fall. - Times Higher Education, http://www.timeshighereducation.co.uk/story.asp?storycode $=411731$ (15.11.2019).

Kirby, A. 2012. The Death of Postmodernism and Beyond. - Philosophy Now, 58 (November/December 2012), http://www.philosophynow.org/issues/58/The Death_of_Postmodernism_And_Beyond (15.11.2019).

McShea, T. 2014. The Last of Us review, Gamespot. https://www.gamespot.com/reviews/ the-last-of-us-review/1900-6409197/ (15.11.2019).

Morgado, M. A. 2014. Fashion Phenomena and the Post-postmodern Condition. Fashion, Style and Popular Culture, 1(3), 313-339. https://doi.org/10.1386/ fspc.1.3.313_1

Naughty Dog 2014. The Last of Us (Remastered). Sony Computer Entertainment. [A game.]

Radchenko, S. 2017. Traditions of Carnival and Normative Cultures in Mykola Hohol's Story Collections "Evenings on a Farm near Dikanka” and "St. Petersburg Stories”. Word and Time, 10, 21-30.

Radchenko, S. 2019. Bleeding Edge of Postmodernism: Metamodern Writing in the Latest Thomas Pynchon's novel. - Interlitteraria, 24 (2), 495-508. https://doi.org/ 10.12697/IL.2019.24.2.17

Sartori, P. 2013. The Last of Us - review. - The Guardian, 5 June, https://www. theguardian.com/technology/gamesblog/2013/jun/05/the-last-of-us-ps3-videogame-review (17.05.2020).

Syundukov, N., Svishchenko, K. 2016. Interview with Robin van den Akker. - Metamodern, http://metamodernizm.ru/robin-van-den-akker/ (15.11. 2019).

Timmer, N. 2010. Do You Feel It Too? The Post-Postmodern Syndrome in American Fiction at the Turn of the Millennium. Amsterdam; New York: Rodopi.

Van den Akker, R., Gibbons, A., Vermeulen, T., eds. 2017. Metamodernism: Historicity, Affect, and Depth after Postmodernism. Maryland: Rowman \& Littlefield International.

Vermeulen, T., Van den Akker, R. 2010. Notes on Metamodernism. - Journal of Aesthetics and Culture, 2(e1). https://doi.org/10.3402/jac.v2i0.5677

Vermeulen, T., Van den Akker, R. 2015. Misunderstandings and Clarifications. -

Notes on Metamodernism, http://www.metamodernism.com/2015/06/03/ misunderstandings-and-clarifications/ (15.11.2019).

Wallace, D. F. 1993. E Unibus Pluram: Television and U.S. Fiction. - Review of Contemporary Fiction, 13 (2), 151-94.

Wallace, D. F. 2006. Infinite Jest. New York: Little Brown.

Wallace, D. F. 2007. Certainly the End of Something or Other, One Would Sort of Have to Think. - D. Foster Wallace, Consider the Lobster and Other Essays. London: Abacus, 51-59. 